carbamylcholine

cystic fibrosis exocrine cells
$\mathrm{K}^{+}$efflux submandibular gland

\title{
Cystic Fibrosis Factors: Effect of Serum on the Secretory Response of Dispersed Rat Submandibular Cells
}

\author{
T. W. SEALE, ${ }^{(35)}$ M. FLUX, O. M. RENNERT, D. O. QUISSELL, K. A. BARZEN, and J. L. LAFFERTY \\ Department of Pediatrics, University of Oklahoma Health Sciences Center, Oklahoma City, Oklahoma, and \\ Department of Pharmacology, University of Colorado Health Sciences Center, Denver, Colorado, USA
}

\begin{abstract}
Summary
The action of serum from cystic fibrosis patients on the intracellular maintenance, efflux, and uptake of potassium ions in dispersed acinar cells from the rat submandibular gland, a seromucous salivary gland, was investigated in an attempt to demonstrate the presence of factors affecting ion-coupled secretion. No effects specific to cystic fibrosis serum were demonstrated upon the following parameters of potassium transport: (1) maximal stimulation of $\mathrm{K}^{+}$efflux by the cholinergic agonist carbamylcholine; (2) the dose-response curve of $\mathrm{K}^{+}$efflux in reponse to carbamylcholine; (3) re-entry of $\mathrm{K}^{+}$into cells after carbamylcholine stimulation; (4) the maintenance of $\mathrm{K}^{+}$in the absence of added effectors. No differences were observed between cells pretreated with serum and cells to which serum was added at the time of cholinergic stimulation of secretion. At high concentrations, serum from both normal individuals and those with cystic fibrosis severely damaged the cells in a rapid and irreversible fashion. $\mathrm{K}^{+}$transport has a direct, closely coupled, specific relationship to secretory activity and is $\mathrm{Ca}^{++}$dependent in this system. From these observations, we conclude that serum from individuals with cystic fibrosis does not contain chemical compounds which specifically alter the major components of ion-coupling to secretion or the secretory process itself in salivary gland acinar cells.
\end{abstract}

\section{Speculation}

If a cystic fibrosis factor affecting ion-coupled exocrine secretion exists in serum, it is present at concentrations too low to be detected or acts upon a cell type other than the acinar cell.

The electrolyte abnormality in eccrine sweat of cystic fibrosis (CF) patients, was first described by di Sant'Agnese et al. (8) in 1953. This quantitative increase in sweat electrolytes is the phenotypic change most consistently demonstrable in the CF patient. Because this finding is independent of the age or the clinical status of the patient $(1,10,29)$, the electrolyte abnormality appears to be a primary manifestation of the basic molecular defect underlying $\mathrm{CF}$. There is no major morphologic alteration of the sweat gland (19). The elevated concentrations of sweat electrolytes reflect a disturbance in cation transport which is generalized among exocrine glands and restricted to them. Increased concentrations of electrolytes are a regular feature of mixed salivary gland and parotid saliva $(4,9,14)$, and quantitative abnormalities in ion composition of other exocrine secretions also occur (7).

Several observations suggest that the electrolyte abnormality is mediated by a humoral component. Retrograde perfusion of sweat from patients with CF into the ducts of rat parotid glands inhibits $\mathrm{Na}^{+}$reabsorption from the primary secretory product of the parotid glands $(16,17)$. Intraluminal injection of sweat from $C F$ patients into normal sweat glands in situ induces a defect in $\mathrm{Na}^{+}$ reabsorption upon subsequent stimulation of sweat secretion with pilocarpine (13). In vitro microperfusion of CF sweat exerts a similar effect upon the normal sweat gland (15). Mixed saliva and saliva from the sublingual, submandibular, and submucosal glands of patients with CF inhibit cation reabsorption in the rat parotid gland bioassay (32) but have no specific effect on erythrocyte cation transport (12). Although serum from patients with $\mathrm{CF}$ also has been reported to contain bioactive "factors" which are not present, or present in lower concentrations, in serum from normal individuals $(2,5,6,31,33)$, no quantitative assessment of their activity upon exocrine cells has been reported.

The cardinal nature of the exocrine gland dysfunction in $\mathrm{CF}$, the humoral nature of the inhibitors of sweat and salivary gland cation transport, and the existence of bioactive serum factors led us to investigate the specific capacity of $C F$ serum to modulate cation transport in cells of the rat submandibular gland, a seromucous exocrine gland. In this gland and other exocrine glands, $\alpha$-adrenergic and muscarinic cholinergic agonists as well as certain polypeptides are known to stimulate secretory activity $(18,20,21$, 25 , 26). An early event associated with this stimulation is the marked and rapid change in membrane permeability to $\mathrm{K}^{+}(18$, $20,23,26,27,30$ ), and the release of intracellular $\mathrm{K}^{+}$by these secretagogues is dependent upon extracellular $\mathrm{Ca}^{++}(21,22,24$, $27,30)$. The dispersed submandibular gland preparation thus allows, in a single bioassay, the search for CF factor(s) which modify acinar cell receptor response to secretagogues, which alter the distinct ion channels involved in cation efflux and re-entry, or which effect changes in $\mathrm{Ca}^{++}$homeostastis in these cells. A significant alteration of any of these components of the secretory process by CF factor(s) is expected to lead to a demonstrable change in $\mathrm{K}^{+}$transport. This bioassay also was chosen for the following additional reasons: (1) it is an appropriate model system because it is a mammalian exocrine gland, one which is pathophysiologically altered in CF; (2) retrograde perfusion experiments have suggested that a closely related gland from the rat, the parotid, is responsive to CF humoral factor(s); (3) dispersed cell suspension of this organ has been perfected, obviating many technical problems associated with in vivo perfusion and in vitro gland slice experiments (21-23); (4) a pharmacologic description of the ion-coupled secretory response is available (23-25); (5) responses of the bioassay are readily quantitated, a necessary attribute for the rigorous demonstration and characterization of a bioactive factor.

\section{METHODS}

Blood was obtained from three female and four male patients with CF, ages 8 to 22 years, who had clinical, radiologic, and sweat electrolyte findings classical for this disease. All were out- 
patients of the Cystic Fibrosis Center of Oklahoma Children's Memorial Hospital and were receiving pancreatic supplements (Pancrease; Johnson \& Johnson, New Brunswick, NJ). Two patients were receiving carbenicillin, three were receiving oxytetracycline, and two were not being treated with antibiotics. Normal subjects serving as age (10 to 23 years) and sex-matched controls were healthy individuals taking no medications and who had no personal or family history of CF. Informed consent of all subjects was obtained according to Department of Health, Education, and Welfare guidelines.

\section{PREPARATION OF DISPERSED CELL SUSPENSION}

Rat submandibular gland cells were obtained by enzymatic dispersion using chromatographically purified collagenase and hyaluronidase according to the method recently developed by Quissell and Redman (25). Male Sprague-Dawley rats (approximately $200 \mathrm{~g}$ ) obtained from Charles River Breeding Laboratory were anesthetized by intraperitoneal injection of sodium pentobarbital (6 to $10 \mathrm{mg} / 100 \mathrm{~g}$ body weight), and after severing the abdominal aorta to effect exsanguination, the submandibular glands were removed. The submandibular glands were dissected from the sublingual glands, quickly minced in a dispersion solution of Ca-, Mg-, free Hanks' salt solution containing $15 \mathrm{mM} 4-$ (2-hydroxyethyl)-piperazineethanesulfonic acid buffer, $\mathrm{pH} 7.4$ with $75 \mathrm{U} / \mathrm{ml}$ chromatographically purified collagenase (Worthington Biochemical Corp., Freehald, $\mathrm{NJ}$ ) and $1.0 \mathrm{mg} / \mathrm{ml}$ hyaluronidase (Sigma Chemical Co., St. Louis, MO). The suspension was incubated in a gyrotory shaker for $60 \mathrm{~min}$ at $37^{\circ}$ in an atmosphere of $95 \% \mathrm{O}_{2}-5 \% \mathrm{CO}_{2}$. After incubation, the cells were washed twice in the suspending buffer without enzymes and passed through a nylon mesh to separate the cells from undigested tissue. The suspension was pelleted by gentle centrifugation $(600$ $\times \mathrm{g}$ for $3 \mathrm{~min}$ ) and then resuspended in modified Hanks' salt solution containing $15 \mathrm{mM}$ 4-(2-hydroxyethyl)-piperazineethanesulfonic acid and $2 \%$ bovine serum albumin (Sigma Chemical Co.). Incubation was continued as above, and the $\mathrm{pH}$ was maintained throughout by addition of $0.1 \mathrm{M} \mathrm{Na} \mathrm{PO}_{4}$. Cells were allowed to equilibrate for $30 \mathrm{~min}$ before the initiation of experiments.

\section{PREPARATION OF SERUM SAMPLES}

Blood was collected by venapuncture using a plastic syringe and was immediately transferred to either a glass tube or a polypropylene tube prechilled in an ice- $\mathrm{H}_{2} \mathrm{O}$ bath. Specimens were chilled and then allowed to clot at $4^{\circ} \mathrm{C}$. (Maximum time never exceeded $4 \mathrm{hr}$ ). After centrifugation at $1000 \times g$ at $4^{\circ} \mathrm{C}$ for $20 \mathrm{~min}$, the serum was removed with a polypropylene pipetter and transferred to plastic tubes. Most samples were stored for 1 to 2 wk at $-35^{\circ} \mathrm{C}$ but several were assayed immediately after preparation. Frozen specimens were rapidly thawed at $37^{\circ} \mathrm{C}$ (within 5 $\min$ ) just before usage and were kept in an ice- $\mathrm{H}_{2} \mathrm{O}$ bath. Specimens were thawed only once and were then discarded after use.

\section{NET $\mathrm{K}^{+}$TRANSPORT STUDIES}

The cell suspension was adjusted with fresh incubation medium to give a packed cell volume to medium volume (hematocrit) of $3 \%$. To determine $\mathrm{K}^{+}$and $\mathrm{Na}^{+}$in the medium at 0 time, $50 \mu \mathrm{l}$ of cell suspension was removed, centrifuged in an Eppendorf Microcentrifuge at $11,000 \mathrm{rpm}$ for $1 \mathrm{~min}$ and the supernatant was analyzed in a Beckman flame photometer. The total $\mathrm{K}^{+}$and $\mathrm{Na}^{+}$ concentration in the cell suspension was determined on supernatant after sonication of the cell suspension. After the addition of agonist (carbamylcholine chloride; Sigma Chemical Co.), serum, or both, samples were removed at various time intervals and centrifuged. Each assay was performed twice, and ion concentration was determined in duplicate. The amount of $\mathrm{K}^{+}$released into the medium was expressed as percentage of the total intracellular $\mathrm{K}^{+}$available for release. The amount of available intracellular $\mathrm{K}^{+}$ s determined by subtracting the medium $\mathrm{K}^{+}$concentration at 0 time from the total $\mathrm{K}^{+}$concentration in the supernatant following disruption of the cell suspension by sonication.

\section{RESULTS}

The action of a cholinergic agonist on acinar cell secretory activity illustrates how net $\mathrm{K}^{+}$transport can be utilized as a chemical marker for the detection of $C F$ factors which affect secretion. The kinetics of the net change in $\mathrm{K}^{+}$levels in rat submandibular cells in response to stimulation by an optimal concentration of carbamylcholine is shown in Figure 1. The rapid net efflux of $\mathrm{K}^{+}$which accompanies the secretory response reaches a maximum at about $45 \mathrm{sec}$ and results in extracellularization of 40 to $50 \%$ of the total intracellular quantity of this ion. Net efflux is followed by a somewhat slower uptake phase in which most of the extracellularized $\mathrm{K}^{+}$re-enters the acinar cells. No net $\mathrm{K}^{+}$ release occurs in the absence of agonist. The logarithnic doseresponse curve (Fig. 2) shows a steep response gradient with a maximum at approximately $2 \times 10^{-5} \mathrm{M}$ carbamylcholine and a half-maximal response at approximately $1 \times 10^{-6} \mathrm{M}$.

To examine the intrinsic ability of $\mathrm{CF}$ and normal serum to promote ion flux in submandibular cells, we incubated $2 \mathrm{ml}$ of cell suspension with varying amounts of serum in the presence or absence of the secretagogue, carbamylcholine. Serum volumes of 1 to $100 \mu \mathrm{l}$ had no effect on enhancing $\mathrm{K}^{+}$efflux in the absence of carbamylcholine. A representative example is shown in Figure 3. $\mathrm{CF}$ and normal serum volumes of 500 and $750 \mu \mathrm{l}$ rapidly and irreversibly damaged the cells as evidenced by increased total $\mathrm{K}^{+}$ efflux into the medium, the altered time course of $\mathrm{K}^{+}$release, and interference with the uptake phase after carbamylcholine stimulation (Fig. 3). Maximal stimulation of $\mathrm{K}^{+}$release by cholinergic effectors is between 40 and $50 \%$ of the total intracellular amount, whereas high concentrations of serum resulted in 60 to $85 \%$ release of $\mathrm{K}^{+}$within $10 \mathrm{~min}$. The time course in the presence of high serum levels does not follow the rapid efflux and subsequent reentry phases seen with carbamylcholine alone. $\mathrm{K}^{+}$efflux continues to increase with time, and the uptake phase is abolished. No significant differences were seen between $C F$ and normal serum in producing these apparantly nonspecific effects. There was no effect of normal serum on the maximal carbamylcholine-stimulated $\mathrm{K}^{+}$efflux, but the re-entry phase was inhibited partially upon addition of serum volumes of $250 \mu$ l (Fig. 3).

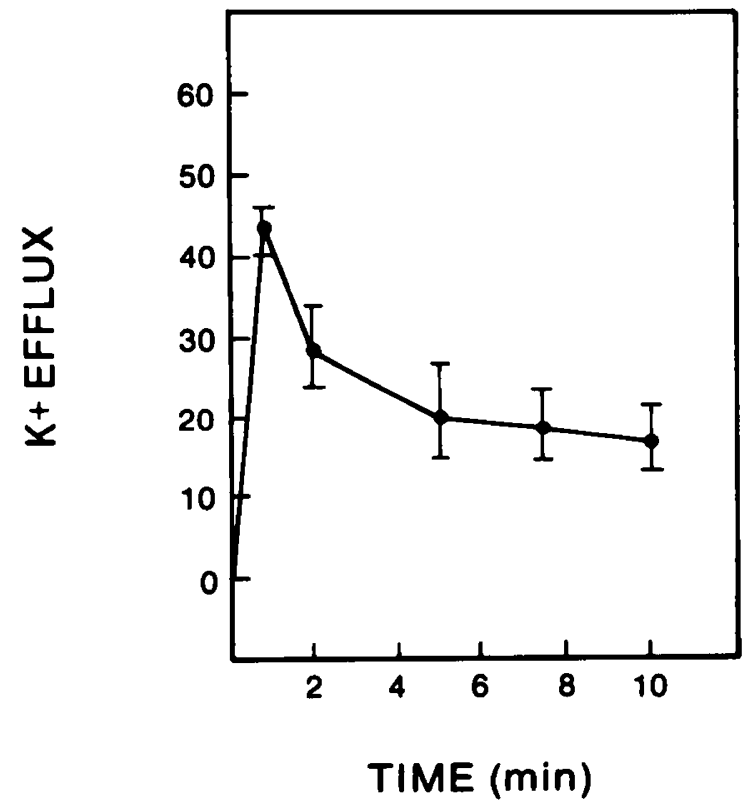

Fig. 1. Time course of net $\mathrm{K}^{+}$efflux from dispersed rat submandibular cells after stimulation in the presence of $10^{-5} \mathrm{M}$ carbamylcholine. Each value represents the mean and S.D. of four separate experiments and is expressed as a percentage of the total cellular $\mathrm{K}^{+}$available for release. 


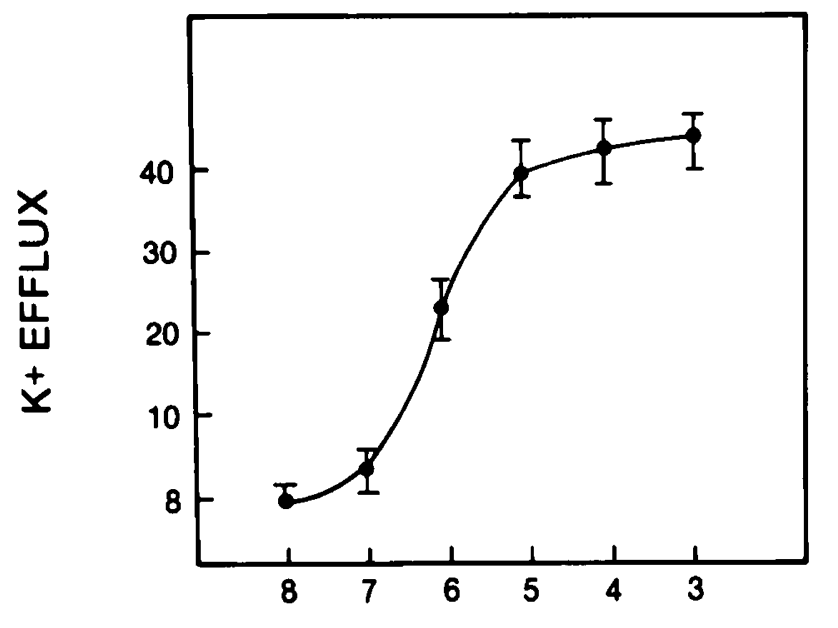

\section{-LOG CARBAMYLCHOLINE CONCENTRATION (M)}

Fig. 2. Net $\mathrm{K}^{+}$efflux from dispersed rat submandibular cells at $45 \mathrm{sec}$ after stimulation by various concentrations of carbamylcholine. Values are expressed as a percentage of the total cellular $\mathrm{K}^{+}$available for release and represent the mean and S.D. of two separate experiments.

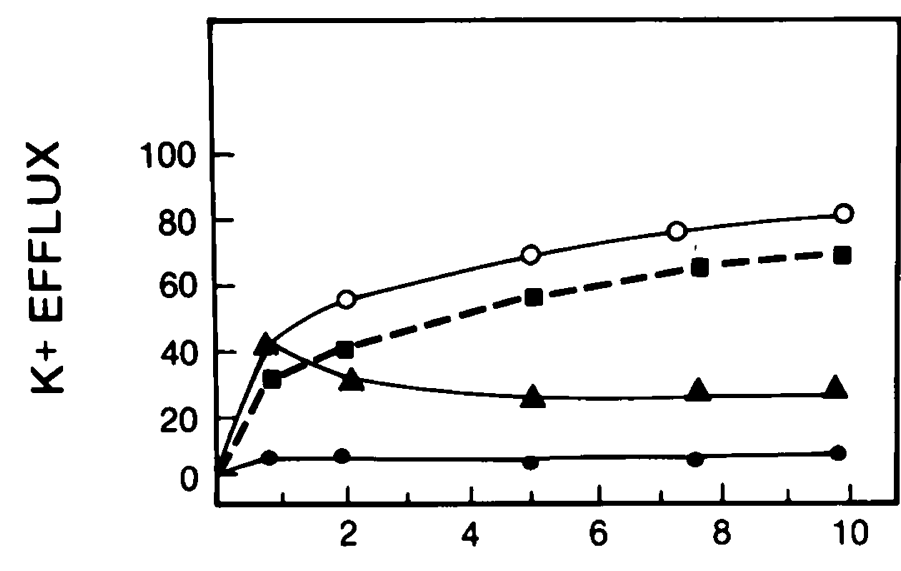

TIME (min)

Fig. 3. The effect of different serum concentrations on net $\mathrm{K}^{+}$efflux from dispersed rat submandibular cells. Values are expressed as a percentage of the total cellular $\mathrm{K}^{+}$available for release. no addition or addition of 1 to $100 \mu \mathrm{l}$ of $\mathrm{CF}$ or normal serum alone; $O$, addition of 750 $\mu \mathrm{l}$ of normal serum plus $10^{-5} \mathrm{M}$ carbamylcholine; $750 \mu \mathrm{l}$ of $\mathrm{CF}$ serum (not shown) produced an identical response; $\square$, addition of $500 \mu$ l of normal serum plus $10^{-6} \mathrm{M}$ carbamylcholine; a similar volume of $\mathrm{CF}$ serum (not shown) produced an identical response; $\Delta$, addition of $250 \mu 1$ of normal serum; the same volume of $\mathrm{CF}$ serum produced an identical response.

Because of the nonspecific effects of normal serum and the failure to see a differential effect of CF serum on $\mathrm{K}^{+}$transport at serum volumes $\geq 250 \mu \mathrm{l}$, detailed analyses of several $C F$ and normal serum specimens were carried out at the maximal concentration of normal serum $(100 \mu \mathrm{l})$ which had no effect on the bioassay system. To determine if CF serum potentiates the effect of a cholinergic agonist on submandibular cells, a fixed volume $(100 \mu \mathrm{l})$ of serum was added to cell suspensions simultaneously with the addition of different concentrations of agonist, and the maximal net $\mathrm{K}^{+}$efflux was determined after $45 \mathrm{sec}$ (Fig. 4). Serum did not elicit the efflux of significantly more $\mathrm{K}^{+}$from the cells at any concentration of agonist. As shown in Figure 4, there was no significant difference between the effect of $\mathrm{CF}$ and normal serum, nor was the pattern of passive efflux significantly altered from that seen in the absence of serum (Fig. 2). No effect was observed on cellular $\mathrm{Na}^{+}$levels. The effects of sera from seven $\mathrm{CF}$ and several normal individuals on $\mathrm{K}^{+}$efflux at high $\left(10^{-5} \mathrm{M}\right)$ and low $\left(10^{-6} \mathrm{M}\right)$ carbamylcholine concentration is summarized in Table 1 .

Because there was no observed enhancement of net $\mathrm{K}^{+}$efflux by $\mathrm{CF}$ serum at any agonist concentration (neither greater net extracellularization at maximal stimulation by secretagogue nor potentiation of the action of suboptimal concentrations of the agonist), the ability of CF serum to inhibit the re-entry phase of $\mathrm{K}^{+}$transport was investigated. Serum $(100 \mu \mathrm{l})$ was added simultaneously with $10^{-5} \mathrm{M}$ agonist and the $\mathrm{K}^{+}$concentration in the medium was determined over a 10-min interval (Fig. 5). No differential effect of the $\mathrm{CF}$ serum was observed either upon the net influx of $\mathrm{K}^{+}$or upon the apparent rate of $\mathrm{K}^{+}$influx subsequent to agonist stimulation. A summary of the data obtained for CF patients and controls is provided in Table 2.

Several different additional control experiments also were performed to clarify certain aspects of these experiments: (1) the effect of fresh versus frozen serum; (2) the effect of clotting blood

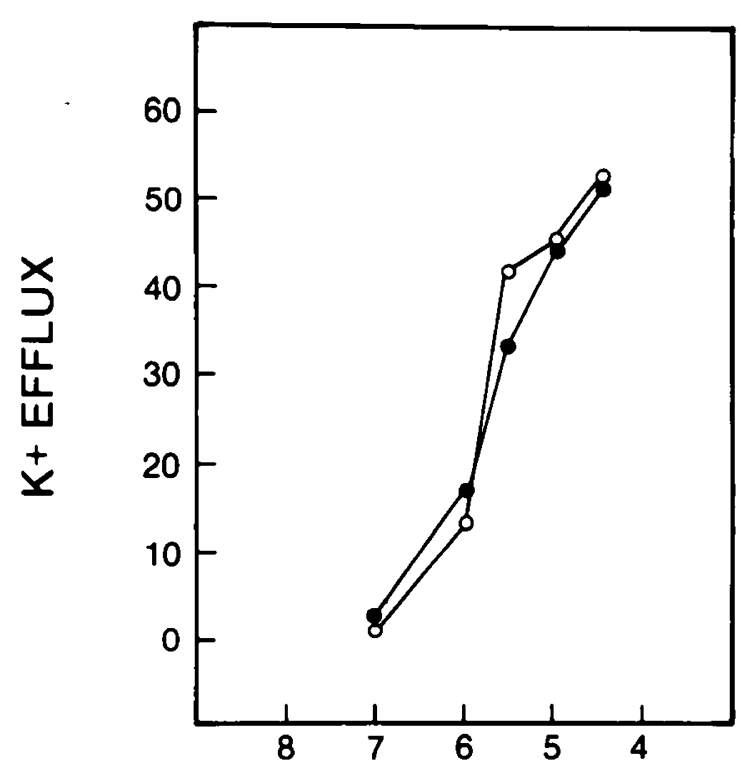

\section{-LOG CARBAMYLCHOLINE CONCENTRATION (M)}

Fig. 4. Net $\mathrm{K}^{+}$efflux from dispersed rat submandibular cells at $45 \mathrm{sec}$ after stimulation by various concentrations of carbamylcholine in the presence of CF $(O)$ or normal $(O)$ serum. Values are expressed as a percentage of the total cellular $\mathrm{K}^{+}$available for release.

Table 1. Effect of serum from $C F$ and normal individuals on carbamylcholine-stimulated potassium efflux from rat submandibular gland cells

\begin{tabular}{lll}
\hline & \multicolumn{2}{c}{ Carbamylcholine concentration } \\
\cline { 2 - 3 } Additions to cells & $10^{-5} \mathbf{M}$ & $10^{-6} \mathbf{M}$ \\
\hline None & $44 \pm 2^{2}$ & $15 \pm 6$ \\
CF serum & $45 \pm 5$ & $17 \pm 2$ \\
Normal serum & $47 \pm 5$ & $15 \pm 1$ \\
\hline
\end{tabular}

'Seven $\mathrm{CF}$ and five normal sera were examined at $10^{-5} \mathrm{M}$ carbamylcholine; five $\mathrm{CF}$ and three normal sera were examined at $10^{-6} \mathrm{M}$ agonist. Each was assayed in duplicate and a control with agonist but withor serum assayed at the same time.

${ }^{2}$ Mean \pm S.D. of the percentage of total cellular $\mathrm{K}^{+}$found in medium $45 \mathrm{sec}$ after addition of carbamylcholine with or without si taneous addition of serum. 


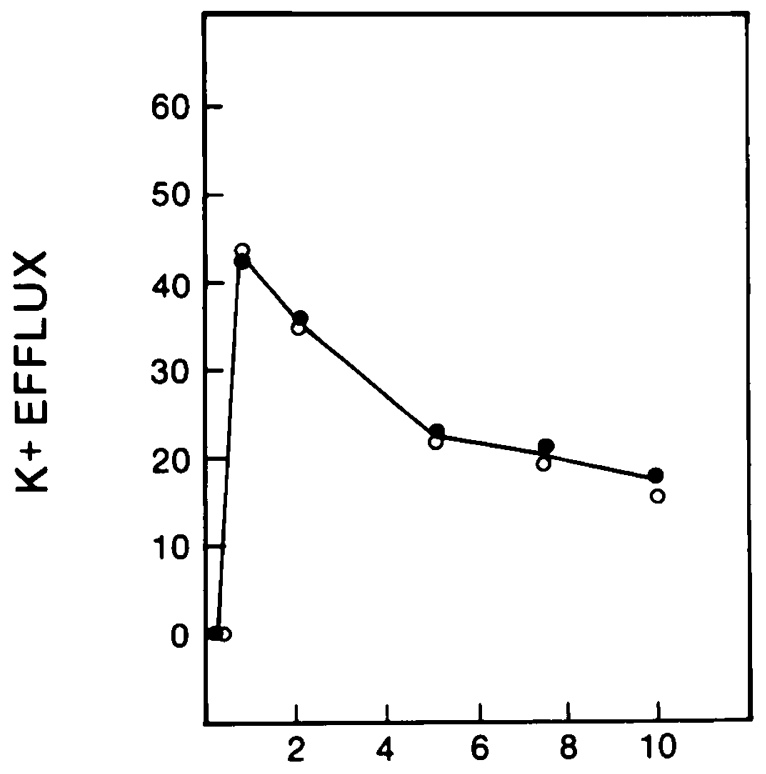

TIME (min)

Fig. 5. The effect of $C F$ and normal serum on the time course of net $\mathrm{K}^{+}$efflux and reentry in dispersed rat submandibular cells. CF $(\Theta)$ or normal $(O)$ serum was added simultaneously with $10^{-5} \mathrm{M}$ carbamylcholine. Values are expressed as a percentage of the total cellular $\mathrm{K}^{+}$available for release.

Table 2. Effect of serum from $C F$ and normal individuals on re-entry of potassium into rat submandibular cells after carbamylcholine-stimulated secretion

\begin{tabular}{lc}
\hline Additions to cells & $\begin{array}{c}\text { Percentage of extracellularized } \\
\mathbf{K}^{+} \text {re-entering cells }\end{array}$ \\
\hline None & $57 \pm 8^{1}$ \\
CF serum & $62 \pm 5$ \\
Normal serum & $55 \pm 12$ \\
\hline
\end{tabular}

${ }^{1}$ Means $(n=5) \pm$ S.D. of the percentage of the maximal $\mathrm{K}^{+}$extracellularized (in response to $10^{-5} \mathrm{M}$ carbamylcholine) that had re-entered the cells $10 \mathrm{~min}$ after addition of the secretagogue.

in glass versus in polypropylene tubes; (3) the effect of preincubating cells with serum for $10 \mathrm{~min}$ before the addition of secretagogue; (4) the effect of removing the albumin from the suspending medium on the activity of CF serum. No significant difference in net $\mathrm{K}^{+}$movement was observed between the action of fresh and frozen serum, the effect of glass or plastic tubes used in serum preparation or upon preincubation of cells with serum before the addition of carbamylcholine. Removal of the albumin, which might conceivably bind and thus inactivate a serum factor, resulted in cell death with loss of most of the cellular $\mathrm{K}^{+}$into the medium in a short period. There was no difference in the effect of CF and normal serum in this process.

\section{DISCUSSION}

Inasmuch as Spock et al. (31) first described the ability of CF serum to disrupt ciliary rhythm in rabbit tracheal explants, there has been a continuing attempt to conclusively establish the presence of unique bioactive humoral factors in CF individuals and to exploit such activities to gain better insight into the molecular basis of this disease. Among the activities reported to occur in serum, saliva, or sweat from the CF patient are inhibition of ciliary movement $(2,6,31)$, stimulation of polymorphonuclear leukocyte degranulation (5), inhibition of alveolar macrophage phagocytic activity (33), inhibition of the glycogen debranching enzyme (11), and interference with cation handling during the secretory process of the salivary gland $(16,17,32)$ and the s'reat gland $(13,15)$. The clinical presentation in the patient implies exocrine gland target specificity if these factors have a relationship to the pathophysiology of CF. In view of the multiplicity of bioactive factors apparently associated with CF serum and the activity in saliva and sweat which may lead to elevated sweat electrolytes in CF, we sought to detect and to quantitate the action of serum factors which interfered with cation transport during exocrine gland secretory processes.

The dispersed cell suspension system of the rat submandibular gland in principle offers several technical advantages over other available bioassays: (1) large preparations of cells, predominantly of the acinar type, can be obtained so that response homogeneity during multiple assays is assured; (2) a large number of assays can be performed in a short time as compared to technically complex, time-consuming assays such as parotid retrograde perfusion; (3) secretion by the cells closely parallels that found in vivo, yet diffusion problems and complex cellular interactions are obviated; (4) the secretory response is quantitative, rapid, and reproducible; (5) there exists a broad description of the major features of the secretory process which includes secretagogue receptors and their dose response to specific agonists, kinetics of net $\mathrm{K}^{+}$and $\mathrm{Na}^{+}$ transport and mucin release, and the requirement for divalent cations (23-25).

It is a general finding that agonist stimulation of secretion in exocrine tissue is accompanied by a major change in intracellular $\mathrm{K}^{+}$concentration as an initial, tightly coupled event $(18,20,21$, $26,27,30$ ). This also occurs in the dispersed rat submandibular cell preparation (23). Secretagogue-stimulated release of both mucin and $\mathrm{K}^{+}$from these acinar cells is $\mathrm{Ca}^{++}$dependent $(23,24)$. Thus, $\mathrm{K}^{+}$release should reflect the action of chemical effectors upon several different components of the secretory response including direct activation of the secretory response, secretagoguereceptor interaction, secretion-linked $\mathrm{K}^{+} / \mathrm{Na}^{+}$transport and the mechanism of $\mathrm{Ca}^{++}$-coupling to secretion. For example, $\mathrm{CF}$ factor(s) might be expected to result in increased net extracellular $\mathrm{K}^{+}$ levels by exerting mechanistically different effects: (1) direct stimulation of the $\alpha$-adrenergic or cholinergic receptors in the absence of exogenous "normal" secretagogue; (2) direct activation of secretion by a more distal event in the activation sequence, e.g., acting as a $\mathrm{Ca}^{++}$ionophore (30); (3) augmentation (sensitization) of the normal cellular responses to secretagogues (hyperresponsiveness); (4) promotion of efflux through an ion channel other than that influenced by normal secretagogues; (5) modification of the duration of the response to secretagogues; (6) inhibition of the re-entry phase of ion transport. In the experiments we described herein, these possibilities were examined with regard to acinar cell $\mathrm{K}^{+}$transport, both passive efflux and active transport during the re-entry phase, and none appeared to be affected differentially by $\mathrm{CF}$ serum. Although it is possible that the enzymatic treatment used in the preparation of the dispersed cell cultures may have altered receptors necessary to the action of CF factor(s), this seems unlikely because receptors for $\alpha$-adrenergic and cholinergic agonists are intact. Alternatively, the concentration in serum of the exocrine gland-active CF factor(s) may be too low to detect with this bioassay system.

The preponderance of acinar cells in the dispersed submandibular preparation (25) is an asset for the detection of CF factors which alter secretion itself but is a major limitation for the detection of alterations in processes subsequent to secretion which occur in other cell types. Thus, the ductal cell function of special interest to $\mathrm{CF}, \mathrm{Na}^{+}$reabsorption from the primary secretory fluid of the acinar cell $(15,16,28)$, cannot be investigated in this bioassay system. The inability of serum factors to alter secretory activity of acinar cells is consistent with Mangos' conclusion (15) that humoral factors lead to increased sweat $\mathrm{Na}^{+}$by interfering with ductal cell reabsorption of this ion from the acinar cell primary secretory fluid. If humoral factors actually lead to the pathophysiologic changes which characterize the exocrine glands in $\mathrm{CF}$, then our results suggest that their action does not involve the acinar cell in a significant and primary manner. It must be 
pointed out that there is no proof that serum bioactive factors detected by others are identical to those demonstrated in exocrine gland products, and there has been no previous demonstration of cation transport inhibitory effects induced by the presumed serum CF factors. Our results serve to emphasize the need to develop a technically more feasible system for the detailed physiologic and biochemical analysis of exocrine ductal cell functions and responses of these cells to humoral factors isolated from $\mathrm{CF}$ patients.

\section{REFERENCES AND NOTES}

I. Anderson, C. M., and Freeman. M.: Sweat test results in normal persons of different ages compared with families with fibrocystic disease of the pancreas. Arch. Dis. Child., 35: 581 (1960).

2. Bowman, B. H., McCombs, M. L., and Lockhart, L. H.: Cystic fibrosis: characterization of the inhibitor of ciliary action in oyster gills. Science (Wash. D. C.). 167: 871 (1970).

3. Cage, G. W.. Dobson, R. L., and Waller, R.: Sweat gland function in cystic fibrosis. J. Clin. Invest., 45: 1373 (1966).

4. Chauncey, H. H., Levine, D. M., Kass, G., Shwachman, H., Henriques, B. L., and Kulczyiki, L. L.: Composition of human saliva: parotid gland secretory rate and electrolyte concentration in children with cystic fibrosis. Arch. Oral Biol., 7: 707 (1962).

5. Conod, E. J., Conover, J. H., and Hirschhorn, K.: Demonstration of human leukocyte degranulation induced by sera from homozygotes and heterozygotes for cystic fibrosis. Pediatr. Res., 9: 724 (1975)

6. Conover. J. H., Bontorte, R. J., Hathaway, P., Paciuc, S., Conod, E. J., Hirschhorn, K., and Kopel, F. B.: Studies on ciliary dyskinesia factor in cystic fibrosis. I. Bioassay and heterozygote detection. Pediatr. Res., 7: 220 (1973).

7. Dearborn, D. G. In: J. A. Mangos, R. C. Talamo: Cystic Fibrosis: Projections Into the Future. p. 179 (1976) Water and electrolytes of exocrine secretions. Stratton Intercontinental Book Co., New York.

8. di Sant'Agnese, P. A., Darling, R. C., Perera, G. A., and Shea, E.: Abnormal electrolyte composition of sweat in cystic fibrosis of the pancreas. Pediatrics, 12: 549 (1953).

9. di Sant'Agnese, P. A., Grossman, H., Darling, R. C., and Denning, C. R.: Saliva, tears and duodenal contents in cystic fibrosis of the pancreas. Pediatrics, 22: 507 (1958).

10. Emrich, H. M., Stoll, E., Friolet, B., Colombo, J. P., Richterich, R., and Rossi, E.: Sweat composition in relation to rate of sweating in patients with cystic fibrosis of the pancreas. Pediatr. Res., 2: 464 (1968).

11. Gillard, B. K., Feig, S. A., Harrison, G. M., and Nelson, T. E.: Cystic fibrosis: enzymatic detection of a ciliostatic factor. Pediatr. Res., 10: 907 (1976).

12. Grinwald, P. M., and Segal, M. B.: Effect of saliva from cystic fibrosis patients and from normal subjects on red blood cell sodium transport. Pediatr. Res., 12: 1 (1978).

13. Kaiser. D. Drack, E., and Rossi. E.: Effect of cystic fibrosis sweat on sodium reabsorption by the normal sweat gland. Pediatr. Res., 5: 167 (1971).

14. Mandel, I. D., Kutscher, A., Denning, C. R., Thompson, R. H.. Jr., and Zegarelli, E. V.: Salivary studies in cystic fibrosis. Am. J. Dis. Child., 113: 431 (1967).

15. Mangos, J. A.: Microperfusion study of the sweat gland abnormality in cystic fibrosis. Texas Reports Biol. Med. 31: 651 (1973).

Copyright $(1) 1980$ International Pediatric Research Foundation, Inc $0031-3998 / 80 / 1412-1398 \$ 02.00 / 0$
16. Mangos, J. A., and McSherry, N. R.: Sodium transport: inhibitory factor in sweat of patients with cystic fibrosis. Science (Wash. D. C.), 158: 135 (1967).

17. Mangos. J. A., and McSherry, N. R.: Studies on the mechanism of inhibition of sodium transport in cystic fibrosis of the pancreas. Pediatr. Res., 2: 378 (1968).

18. Martinez, J. R., and Quissell, D. O.: Potassium release from the rat submaxillary gland in vitro. II. Induction by parasympathomimetic secretagogues. J. Pharmacol. Exp. Ther., 199: 518 (1976).

19. Munger. B. L., Brusilow, S. W., and Cooke, R. E.: An electron microscopic study of eccrine sweat glands in patients with cystic fibrosis of the pancreas. J. Pediatr., 59: 497 (1961)

20. Peterson, O. H.: Formation of saliva and potassium transport in the perfused cat submandibular gland. J. Physiol. (Lond.), 216: 129 (1971).

21. Putney, J. W., Jr.: Muscarinic, $\alpha$-adrenergic and peptide receptor regulate the same calcium influx sites in the parotid gland. J. Physiol. (Lond.), 268: 139 (1977).

22. Putney. J. W., Jr.: Role of calcium in the fade of the potassium release response in the rat parotid gland. J. Physiol. (Lond.), 281: 383 (1978).

23. Quissell, D. O.: The secretory response of dispersed rat submandibular cells: 1 Potassium release. Am. J. Physiol. 238 (Cell Physiol. 7): C90 (1980).

24. Quissel, D. O., and Barzen, K. A.: The secretory response of dispersed rat submandibular cells: II. Mucin secretion. Am. J. Physiol., 238: C99 (1980).

25. Quissell, D. O., and Redman, R. S.: Functional characteristics of dispersed rat submandibular cells. Proc. Natl. Acad. Sci. U. S. A., 76: 2789 (1979).

26. Rudich, L., and Butcher, F. R.: Effect of substance P and eledoison on $K^{+}$efflux amylase release and cyclic nucleotide levels in slices of rat parotid gland Biochim. Biophys. Acta, 444: 704 (1976).

27. Schneyer, L. H., Young, J. A., and Schneyer, C.A.: Salivary secretion of electrolytes. Physiol. Rev.. 52: 720 (1972).

28. Schulz. L. J., and Peter G.: Micropuncture studies of the abnormality in sweat formation in cystic fibrosis. Fed. Proc., 26: 287 (1967).

29. Shwachman, H., and Mohmoodian, A.: Quality of sweat test performance in the diagnosis of cystic fibrosis. Clin. Chem.. 25: 158 (1979).

30. Spearman, T. N., and Pritchard, E. T.: Potassium release from submandibular salivary gland in vitro. Biohim. Biophys. Acta, 466: 198 (1977).

31. Spock, A., Heick, H. M. C., Cress, A., and Logan, W. S.: Abnormal serum factor in patients with cystic fibrosis of the pancreas. Pediatr. Res., $1: 173$ (1967).

32. Taylor, A., Mayo, J. W., Boat, T. F., and Matthews, L. W.: Standardized assay for the sodium reabsorption inhibitory effect and studies of its salivary gland distribution in patients with cystic fibrosis. Pediatr. Res., 8: 861 (1974).

33. Thomassen, M. J., Boxerbaum, B., Demko, C. A., Kuchenbrod, P. J., Dearborn, D. G., and Wood, R. E.: Inhibitory effect of cystic fibrosis serum on Pseudomonas phagocytosis by rabbit and human alveolar macrophages. Pediatr. Res. 13: 1085 (1979).

34. The authors acknowledge the excellent technical assistance of Barbara Farber.

35. Requests for reprints should be addressed to: Dr. Thomas W. Seale, Department of Pediatrics, University of Oklahoma Health Sciences Center, P. O. Box 26901, Oklahoma City, OK 73190 (USA).

36. This research was supported in part by Contract NO1-HR-7-2923 to T. W. Seale and $\mathrm{O}$. M. Rennert from the Public Health Service, National Heart Lung and Blood Institute and by grants from the Cystic Fibrosis Foundation and NIH (DE 04778) to D. O. Quissell. D. O. Quissell is a recipient of a Cystic Fibrosis
Research Scholar Award.

37. Received for publication January 22, 1980

38. Accepted for publication April 22, 1980. 